\title{
A Study in the Short Stories of Kamala Das
}

\section{OPEN ACCESS}

Manuscript ID:

ENG-2020-08033225

Volume: 8

Issue: 3

Month: June

Year: 2020

P-ISSN: 2320-2645

E-ISSN: 2582-3531

Received: 15.04 .2020

Accepted: 20.05.2020

Published: 02.06.2020

Citation:

Tiwari, Jai Shankar. "A

Study in the Short Stories of Kamala Das." Shanlax International Journal of English, vol. 8, no. 3, 2020, pp. 37-41.

DOI:

https://doi.org/10.34293/ english.v8i3.3225

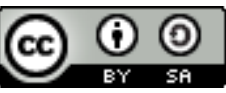

This work is licensed under a Creative Commons Attribution-

ShareAlike 4.0

International License

\author{
Jai Shankar Tiwari \\ Assistant Professor, Department of English \\ Nehru Gram Bharati (Deemed to be) University, Prayagraj, Uttar Pradesh, India \\ https://orcid.org/0000-0003-1541-1286
}

\begin{abstract}
The study has been able to ascertain and prove beyond doubt that Das's prose works are of no less ranking than her poems and that she has effectively employed the short story form to present the predicaments of Indian womanhood and their quest for identity and self-assertion. The exhaustive evaluation and thorough scrutiny taking up various aspects of he stories right from her themes, structure and style, narrative techniques to her portrayal of Indian women, their status in society, and identity crisis have finally led to the emergence of the New Indian woman. Das's feminist approach and overt outlook, along with the quest for a self-determined and self-affirmed identity for Indian women, have been well established through a methodical and exhaustive contemplation of the diverse women characters. The conclusion that emerges from this study undoubtedly corroborates and attests that Kamala Das's name stands at par with the pioneer Indian woman short story writers. Das has efficiently and effectively used the short story genre as a document of social criticism and has established herself as a feminist crusader, campaigning to acquire for the Indian womanhood an independent identity and self-dignity. Das's short story, with its innovative style and techniques, simple language, and concise form, has been brilliantly explored in discussing the problems facing Indian womanhood, especially her search for selfhood. Das has adeptly highlighted and presented her outlooks with the help of her characters. The fact that her English fictional work has remained obscure and un-honored is a sad story and a loss to literature. Keywords: Womanhood, Sufferings, Equality, Society, Violence, Indian writing.
\end{abstract}

Kamala Das, a bilingual and well established Malayalam writer made her mark in the Indian English literary scenario with her poems and autobiography. She merits a place among the most highly acclaimed poets of the twentieth century and notable for the confessional tone, feminist dimension, and celebration of a woman's body in her poems. Das also is known for her frank, bold and controversial outlook, both in life and in literature, stands out for her non-compromising attitude of personal ideals and values. This approach and outlook of Das a well reflected and transferred to all her literary works.

Das's prominent collection of poems are Summer in Calcutta (1965), The Descendants (1967), Old Playhouse and Other Poems (1973), Collected Poems (1984), and Annamalai Poems. Most of these poems have her own experiences and outlooks recorded. This conspicuous craftsmanship and sensitiveness of Das render strength and uniqueness to her poetry, making her readers feel one with her. Das's life and poems go hand-in-hand, and she has indubitable been applauded as a poet par excellence. This well-established status of Das as a brilliant and outstanding poet has won he poems abundant critical acclaims and reviews. 
Kamala Das had become instantly popular with the English reading crowd of India, with her autobiography My Story (1971), an instantaneous runway success. Her autobiography has been translated into eleven languages, and her works included in the syllabi of thirteen international universities. Since then, there was no looking back for her. Recognition reached her in the form of many literary awards like the Kent Award for Asian English writing, Vayalar Award, the Kerala Sahithya Academy Award, and, more recently, the Ezthachan Award. She was also a nominee for the Nobel Prize for literature in 1984.

As one of the major contemporary Indian women writers in English, very less critical acclaim and attention have been awarded to her English fiction. Though her contribution to English literature is negligible quantitatively, qualitatively, she comes next to none in points of reputation and recognition. Her stories have a diverse variety of woman's experiences, and their trials and tribulation recorded. Though her themes and characters have relevance with a woman's present-day life and happenings, critical justice has been denied to her fiction. One cause for this sidelining might be because of the pre-conceived notion of Das as a luminous poet only. This research study has taken into account her eighteen short stories under the title Padmavati, The Harlot and Other Stories (1992) and Alphabet of Lust (1976) and seeks at doing justice to her fictional works, which has unfortunately been denied due fairness and accreditation.

These works have made an effort to justify the claim that her fiction, also equally brilliant as her poems. The work concentrates on analyzing Kamala Das's endeavor in exploring the Indian woman's life and identity through her English short stories and establish her as an equally excellent writer of fiction. Her autobiography My Story is also briefly analyzed to compare and contrast Das with her fictional characters and to affirm that the women personas in her fiction are an extension of Das's individuality.

A thorough study of all Kamala Das's English short stories has been done by making a descriptive, analytical, and comparative study. The ideas drawn out from the study are coherently organized and documented by the MLA Handbook by Joseph
Gibaldi. The study has delved into various aspects of short fiction like theme, character, structure, style, and techniques and also with other related issues like feminism. Das's brilliance and agility as a short story writer have been well affirmed with this wideranging study. It has also helped to conclude with a proper insight into the reasons that prompted Das to choose the short story form to explore and portray Indian woman, her predicaments, and her impending quest for identity.

The first identity of the research work has an in-depth study of the various aspects of the short story genre. Titled "Short Story Tradition: An Overview" this identity deals with a comprehensive investigation into various aspects of this form like its history, development, definition, features, and the major aspects. The identity starts with a meticulous study with a clear illustration of the evolution and establishment of the modern English short story form and the origin of the Indian short story. The history of the earliest extant stories has been probed, which find mention in the literature of the prehistoric times to record its initial origin. The establishment of the short story as an independent literary genre and the factors that led to the birth of the modern short story has been discussed. Edgar Allan Poe and others who were instrumental is establishing the short story as a separate genre have also been studied. The factors that were responsible for the slow decay of this form have been traced. The major writers who promoted in the revival and development of the short story, along with their outstanding works, have been noted.

Different definitions of the short story have been taken up for analysis, and the changes that were involved in the structure and theme of the 20th century English short story have been debated. Essential features that go into the composition of a short story have been listed like unity of impression, motive, purpose, and action, epiphany, and symmetry design, a moment of the crisis, have been discussed. Some of the pioneer and popular writers and their works have been analyzed based on the different characteristic features that they employed in their stories like O'Henry, James Joyce, Anton check, Guy de Maupassant, etc.

The Indian English short stories have been examined, and the wide-ranging influence of the 
Indian stories and their characters like those from the Ramayana and Mahabharata on the modern English form has been studied. The steady development of the Indian English short story and its major writers like R.K. Narayan, Raja Rao, Mulk Raj Anand, Iswaran, and their important works have been traced out and discussed at length. A list of women short story writers, right from Sita and Shanta Devi to the modern-day writers like Anita Desai, Sashi Deshpande, Ruth Prawar Jhabwala, Attia Hossain, have also been dealt with in detail. The study followed by in-depth scrutiny of Kamala Das's English fiction and her effective use of this genre in expressing her views and experiences with special reference to the themes and techniques employed by her. Finally, a brief and concise study has been done to record the achievements and areas of further improvement of this narrative form.

The subject discussed in the titled "Images of Indian Woman" analyses the fundamental relationship between literature, woman and society, and the indispensable effect of each on the other. Firstly, the changes in society that get reflected in literature and the effect that these changes have on the writings and the writers have been studied. Secondly, the diverse aspects of a woman's life, which occupy the center stage of discussion in all literary works, have been analyzed to reveal the impact that literature has in molding the outlook of society and man in particular. This analysis of the interconnection and relation between literature, woman, and society has helped to establish and confirm that literature plays an influential role in shaping the life of a woman and changing the perspective of the society.

The identity followed by a comparative and analytical study of the transforming images of women as depicted in the Indian literature down the different ages. This study has assisted in comprehending and determining the impact that the ancient literature and literary legends, myths, and folklores have had on the present status of an Indian woman and its persistence in the literary backdrop of modern Indian English literature. The story has furthermore contemplated the influence of Indian literature on the Indian English writings and how the writers have employed the medium of English to highlight and resolve the issues of Indian womanhood.
The images of women as depicted in the Indian English literature written by both men and women writers have dealt with separately, and some of the major writers and their works like those of Narayan, Rao, Anand, Desai, Deshpande, etc. discussed. Thus, this study has aided in establishing the longstanding relation between Indian literature and Indian womanhood. The effort of modern Indian English writers, especially that of women writers to change the old archetypal images of womanhood, their endeavor to break free from the shackles of traditional bondage and break conventional norms laid by patriarchy has been discussed. The chapter winds up recording the future responsibility of the writers in transforming the attitude of men and society towards womanhood.

The title "the Feminist Approach in the Short Stories of Kamala Das and her Contemporaries," an exhaustive examination about the women's movement, feminism, and its influence on Indian women writers, has been studied.

The story begins with a thorough evaluation of the term feminism and its diverse implication. An effort to interpret feminism has been made with the help of comments and remarks by established writers and feminists. The causes that led to the rise and spread of feminist literature and feminist literary works have been analyzed and studied in-depth to get a proper interpretation of feminist writers and their perspectives.

In the facets of feminism in Indian English fiction, different facades of Indian feminist literature have been studied, and a general analysis of feminist literary works have been done to get a clear picture of the portrayal of an Indian woman and the impact that the old conventional and mythical image has had on the writings of different age. The new change that has been observed in the writings of modern writers has also been discussed.

The impact of feminism on the Indian women writers has been depicted with the help of different short stories written by them. The perspectives, overtures, and efforts of some of the women writers to illustrate the Indian woman's predicaments through the medium of the short story genre have also been handled in this story. Kamala Das has been compared and contrasted with two of her contemporaries, 
namely Anita Desai and Sashi Deshpande. Their short stories have been taken up for revealing the feministic approach and outlooks of these women writers. The short stories of Kamala Das have been analyzed based on Elaine Showwalter's theory.

Finally, the reflection and resolution of the women writers have been discussed to ascertain the identity of the 21st-century Indian woman and beyond with the help of these literary works. A final account has been drawn out after analyzing the feminist stance of the women writers. The common outlook of these women writers, their endeavors $t$ ascertain a respectable place for Indian womanhood in society, and their efforts in this direction have been recorded.

The titled "Indian Woman's Quest of Identity and Its Assertion." The Indian woman's journey in the quest of her identity is drawn out by the explicit deliberations of the women characters as depicted in the eighteen short stories of Das collected under the title Padmavati, the Harlot and Other Stories.

The title begins with a discussion of the term 'Identity' and 'Quest,' which have been defined, and various aspects concerning a woman's identity, as depicted in the writings of women writers, have been reflected and contested. Coming to the identity-crisis of the Indian woman, different forms of identitycrisis that women face in the family and society, as depicted in the fiction of Indian English women writers, are studied. The fiction of writers like Nayantara Sahgal, Meera Mahadevan, Shobha De, Ruth Pawar, Anita Desai, and Attia Hosain has been discussed.

This story scans through the multifaceted woman characters presented by Kamala Das in her stories. The protagonists of Das's stories portray the change in outlook from a covert to an overt attitude of the Indian woman. The realization and selfconsciousness of a woman's individuality and her assertion of selfhood have been closely examined.

The discussion of English short stories of Das in detail reveals that the quest for identity is the major motif that has been dealt with by Das. The assertiveness of the women characters in roles of mother, wife, lover, and daughter has been discussed to highlight the problems they face from within and outside the family and the dignity and confidence with which they encounter and challenge these predicaments.

The affirmation of self and the change in approach from an enduring and submissive character to the rebelling and questing individual is discussed to show that Das has introduced through her fiction a new face for Indian womanhood. The topic winds up on the note that Das as a writer concentrates on the life of middle-class women, and she handles their problems with agility and sensitivity. Das has tried hard through her characters to reach out to society and make people aware and conscious about the dilemmas and hardships that Indian woman has to undergo in life.

The "Concept of the New Indian Woman draws out from the reflection of the preceding the emergence of the 'New Woman.' This concept is further forcefully confirmed and illustrated with the help of the different female protagonists in two of her lengthy and brilliantly contrived stories, titled "A Doll for the Child Prostitute" and Alphabet of Lust.

Das's New woman characters, as depicted in the story "A Doll for the Child Prostitute," have been individually studied. The crimes, injustice, abuse, and exploitation of women and girl children have been highlighted. Das's effort of initiating through them the bold new women who dare to defy the old conventional norms has been well presented. Das's introduction of a new outlook of thinking by the socially outcast women and their attempts to assert their selfhood and attain a dignified position in society has been portrayed through these women personas.

Another image of the new woman of Das presented through the character of Manasi in the Alphabet of Lust. A strong affirmation of the physical and intellectual individuality of an Indian woman is depicted in this character. Through the character of Manasi, Das has endeavored to challenge and redefine the accepted notions of feminine mystique. This attempt of Das to develop a revived outlook Indian womanhood has been discussed at length here.

A brief analysis of Das's autobiography My Story has also been done to understand the writer and her perspectives about the Indian woman and justify her characters in different stories. Das 
has, through her autobiography, set the standards and tried to inspire the Indian woman to raise her voice to gain her rights. The characters of the last two stories have been discussed and juxtaposed with Das's character, as mentioned in My Story, to determine the development of a new identity that Das has presented to the Indian woman. The study also helps to affirm that Das's fictional characters have been drawn out from her real-life experiences, and her woman characters, especially Manasi, are an extension of her personality.

Finally, the outlook and approach of Kamala Das and her fictional characters have been debated and discussed, its practical applicability in the Indian society has been contested, and a general conclusion of this has been drawn.

In the sixth chapter, the "Conclusion" of the thesis is a general survey of the research deduction. This title is based on the proceedings of her fiction and makes an effort to rate the writer's capacity as a short story writer. An impartial assessment of her areas of success and effective use of different narrative forms has been valued. Her ability to question radical practices and introduce progressive values and attitudes has been highlighted. As a writer, her selfemployed responsibility in creating a new pattern of living and thinking for Indian womanhood has also been stressed. The feminist consciousness and the emphasis of the definitive role of literature in redefining a woman's life in Das's writing have been affirmed with the help of her various short stories. Das's ability to use this comprehensive form in effectively reaching out to the readers to convey her viewpoints has also been underlined with different examples of stories.

The Interview with Kamala Das provides direct and explicit information and views of the writer herself. The interviews also have the unique feature of having recorded her comments and the changes in her outlook after her conversion to Islam. The interview has helped in getting an authentic firsthand report, and a better understanding of the writer and her personal life is a proof to the unquenched search of self-identity of the woman in her-the concept of Indian Woman's quest for identity, which has been interesting and informative. The change from Kamala Das to Kamala Suriya, in her personal life, is a proof to the unquenched search of selfidentity of the woman in her. The concept of Indian woman's quest for identity reaches its zenith, and there is enough reason to believe that should Das give us another fictional work in English, the female protagonist therein would certainly be unparalleled in her identity and assertion.

\section{References}

Bakyaraj, R. "The Feminist Approach in Kamala Das Novel: A Comparative Study." Review of Research, vol. 8, no. 3, 2018, pp. 1-4.

Dwivedi, A.N. Studies in Contemporary Indian English Short Story. B.R. Publishers, New Delhi, 1991.

Foster, E.M. Aspects of the Novel. Edward Arnold, London, 1960.

Frost, Robert. Collected Poems, Prose and Plays. Library of America, New York, 1995.

Kumar, Rajesh. Kamala Das's Work, A Feminist Perspective, 1998.

Naik, M.K. A History of Indian English Literature, Sahitya Akademi, 1982.

Srinivas Iyengar, K.R. Indian Writings in English. 4th edition Sterling Publisher, 1984.

Tawhida Akhter. "Kamala Das: The Voice of Indian Woman's Quest for Liberation." International Journal of Innovative Research \& Development, vol. 2, no. 5, 2013, pp. 16261633.

\section{Author Details}

Dr. Jai Shankar Tiwari, Assistant Professor, Department of English, Nehru Gram Bharati (Deemed to be) University, Prayagraj, Uttar Pradesh, India, Email ID: drjstiwari002830@gmail.com. 